\title{
Acemoglu Joins Mankiw: Effect of Institutions in Growth Through Human Capital
}

\author{
Fabio Gama ${ }^{1}$, Suzana Quinet de Andrade Bastos ${ }^{1}$, Guilherme Cardoso ${ }^{2}$ \\ ${ }^{1}$ Federal University of Juiz de Fora (UFJF) Juiz de Fora, MG 36036-900, Brazil \\ ${ }^{2}$ Federal University of Minas Gerais (UFMG) Belo Horizonte, MG 31270-901, Brazil \\ Correspondence: Fábio Gama, Federal University of Juiz de Fora (UFJF) Juiz de Fora, MG 36036 900, Brazil.
}

Received: November 22, 2019

Accepted: December 19, 2019 Available online: December 24, 2019

doi:10.11114/ijsss.v8i1.4622

URL: https://doi.org/10.11114/ijsss.v8i1.4622

\begin{abstract}
Starting from the Augmented Solow Model developed by Mankiw, Romer, \& Weil (1992), the present paper considered new perspectives in which institutions are considered "fundamental determinants" to explain economic growth. Through the data panel methodology, and with information for the years 2000, 2005 and 2010 from 87 countries, we used the interactive variables mechanism to verify whether the relationship between human capital and GDP per capita is encouraged by the institutions. The results indicate a positive relationship between economic and political institutions with the effect of education on per capita growth of countries, with greater influence of the former.
\end{abstract}

Keywords: human capital, economic growth and institutions

\section{Introduction}

In the theory of economic growth, Harrod (1939) and Domar (1946) relate supply side growth to demand side growth, with investment (physical capital) and the labor force as the main determinants. Solow (1956) (Note 1) adds the growth rate of technology to the model, and both work and technology would grow at constant and exogenous rates over time. In addition, the author includes the concept of decreasing marginal productivity of factors of production, which would ensure the smoothing of demand shocks in the economy by varying capital and wage interest rates. Thus, there would be a tendency for economies to grow at a constant rate over time.

According to Mankiw, Romer, \& Weil (1992), Solow's (1956) model implies that higher savings rates lead to higher output growth and, conversely, increasing population growth rates reduce per capita output, impoverishing the country. The authors ascertain the magnitude of the statistical effect of saving and population growth rate on countries' per capita output, showing that these variables can have their effects reduced by entering the level of human capital in society (Note 2). This artifice (Augmented Solow Model) has had implications for assessing economic growth and the speed of income convergence between nations.

Acemoglu, Gallego, \& Robinson (2014), however, discern the determinants of economic growth between the so-called approximate determinants and the fundamental determinants. The approximate determinants, which include factors of production, innovation, accumulation of physical and human capital; they would not be the origin of the level of prosperity of nations and their differences, but they would characterize prosperity itself. The key determinants are really responsible for questions such as "why are some countries so much more innovative than others?"; "Why do they invest so much more in their education system?" And "Why do people save and invest in physical capital?" With institutions as the key determinants, they would allow growth by raising the level of Total Factor Productivity (technological progress), human capital and physical capital; factors whose evolution characterizes the process of economic development.

In this context one wonders: just as human capital stands for the growth rate of the economy in Mankiw, Romer, \& Weil (1992), are institutions for human capital? That is, can the effect of human capital on per capita income be stimulated by institutions by observing the behavior of gross fixed capital formation, labor force and technology (total factor productivity)?

Thus, the paper proposes to verify whether institutions, omitted by both the Solow Model and the Augmented Solow Model, can be considered country specificities and, thus, a differential factor to explain the effect of human capital on 
GDP per capita. To this end, we add interactive terms in a panel data model with information from 87 countries for the years 2000, 2005 and 2010.

Adding institutions to the human capital model of Mankiw, Romer, \& Weil (1992), allows a more accurate analysis of the relationship between human capital and economic growth, since, according to Acemoglu, Johnson, \& Robinson (2001), as institutions improve, they generate incentives for greater and more efficient investments in human capital, and economic growth is the consequence.

In addition to this introduction, the second section develops the theoretical framework and empirical work. Section 3 presents the database used for the empirical test. Section 4 presents the methodological strategy and methodology used to obtain the results analyzed in section 5. Section 6 presents the conclusions.

\section{Institutions and Economic Performance}

Institutionalist theory has been used to explain the functioning of the economy and to observe how institutional change affects people's way of life and the organization of production in different nations (LOPES, 2015).

North (1991) describes the role of institutions in economic performance. Institutions are constraints created for the political, economic and social interaction structure. They consist of informal restrictions such as sanctions, taboos, customs, traditions and codes of conduct; and formal rules such as constitutions, laws and property rights. Institutions are necessary in today's highly specialized and division of labor society, supported by cooperation among agents to reduce transaction and production costs.

From the perspective of economic growth, North (1981) argues in favor of intellectual property rights, which can offer creators confidence in ideas and innovations (Note 3). In this sense, Glaeser, Porta, Lopez-Desilanez, \& Shileifer (2004) point out that political and economic development need property rights to support investments in human and physical capital and consider this right as a democratic public policy. However, they argue that from an institutional standpoint, pro-investment policies are the consequence of political constraints on government, while from the perspective of political and economic development, these policies in poor countries are largely the choices of their leaders. - generally, without controls or limitations on the exercise of power.

Lopes (2015) indicates that in democratic countries with a high level of social trust (Note 4), individuals may exert pressure for distributive policies aimed at the benefit of the community in opposition to private interests or aimed at increasing social rights. Thus, if these policies come at the expense of investments, growth rates may be reduced.

To understand the reasons for institutional disparities between countries, given that institutions play an important role in economic development, Acemoglu, Johnson, Robinson, \& Yared (2008) understand that imposition of institutional reforms can have little impact on the overall structure or performance of economic institutions if the underlying political balance is left intact. For the authors, the institutional changes that affect the distribution of de jure political power, that pertaining to the power originating from political institutions in society, need to be complemented by changes in the de facto political power source of the elite and reductions in the benefits of policy makers in intensifying the use of de facto political power, the one that arises with the ability of a group to solve its problem of collective action from the resources available for action, such as paramilitary actions, bribery, corruption, among others.

The idea of de jure and de facto institutions is also found in North (1990) in warning that while many Latin American countries have adopted constitutions similar to the US Constitution and property rights (de jure) laws that have successful in promoting the development of many Western countries, the long-term economic performance of these Latin American countries was far lower than in the US, against the enforcement and enforcement mechanisms of the rules that form the real incentive structure (de facto institutions) faced by the economic agents of each country.

Souza Júnior (2013) points out that in many countries, although rules are found that create de jure political institutions coherent with a free democratic society, de facto political institutions may reveal the opposite. According to the author, countries will be considered advanced, in terms of political institutions, if power is not concentrated, depending on the "rules of the game", only on political elites and if the average citizen can have free access to information and can challenge current policies - without the need to make a revolution or organize any kind of armed revolt.

Acemoglu (2009, p.111) defines economic institutions as "rules, regulations, laws and policies that affect economic incentives and, therefore, incentives to invest in technology, physical capital and human capital." According to the authors, while institutions policies determine formal power in society (de jure), the distribution of resources influences effective political power (de facto). These two sources of political power, in turn, affect the choices of economic institutions and the future evolution of political institutions themselves. Economic institutions determine the performance of the economy, both in terms of growth and the distribution of resources in the $t+1$ period, and while fundamental determinants of economic performance, they are endogenous and shaped by the political institutions and distribution of wealth in society. 
In empirical terms, Hall \& Jones (1999) investigate the factors that explain the heterogeneity of labor capital among 127 countries, using data that has been demystified for the years 1970, 1980 and 1990. Under the statistical supports of Ordinary Least Squares and Instrumental Variables, point out that differences in capital accumulation, productivity, and therefore in output per worker, are influenced by differences in government institutions and policies.

Glaeser, Porta, Lopez-Desilanez, \& Shileifer (2004) found in an analysis for 167 countries that human capital is the clearest source of growth than institutions, showing that most of the initially poorest countries come out of poverty through undemocratic policies.

In this same perspective, Acemoglu, Johnson, Robinson, \& Yared (2008), after controlling for the specific effects of each country, find that the positive association between per capita income and democracy disappears. As a justification, they point out that societies conduct their politics and economy in different ways at certain critical moments in their trajectory.

Starting from Acemoglu, Johnson, Robinson, \& Yared (2008), Moral-Benito \& Bartolucci (2012) state that democracy in low-income countries with weaker institutions may be affected by changes in income; however, in high-income countries and more stable institutions, changes in income have no effect on the level of democracy.

In order to verify the role of educational policy on the economic performance of Brazilian states, Dias, Dias, \& Lima (2009), estimate a panel data model for the years 1985 to 2000. Results suggest that increases in education levels have positive effects on GDP per capita growth rates. Moreover, the inverted U-shaped relationship between economic growth and schooling indicates that the effect of schooling on the economic growth rate is initially increasing and decreasing thereafter. This result indicates that institutions are effective in compensating for the declining trajectory of the effect of education on economic performance.

In estimating the determinants of institutions, Souza Júnior (2013) in a sample of 133 countries finds positive and significant estimators of the variables: average adult education; durability index of the political regime; per capita income and variables of institutions lagged in one and two periods. The Gini Index estimator is negative and significant.

Lopes (2015) finds statistical significance in a sample of 79 countries on the impact of democracy and confidence on real GDP per capita growth. In addition to the institution variables, the model has as explanatory variables: education, investment in physical capital and population growth.

\section{Integration of Augmented Solow Model with Institutions}

According to Mankiw, Romer, \& Weil (1992), the initial productivity level of countries differs not only in technology, but also in resources, climate and institutions; so that the term can be broken down into: $A(0)=a+\varepsilon$ where is $a$ constant and $\varepsilon$ represents country specificities. Thus, in the Augmented Solow model institutions are not a treatable variable because, as in Solow (1956) they are expressed in the parameter $A(0)$, which makes a more accurate analysis of their implications for the level of activity over time impossible. However, Mankiw, Romer, \& Weil (1992) innovate in relation to Solow by introducing the human capital factor into the product determination equation (Note 5). In formal terms, the Augmented Solow model can be expressed as (1):

$$
Y(t)=K(t)^{\alpha} H(t)^{\beta}[A(t) L(t)]^{1-\alpha-\beta}, \alpha>0, \beta>0, \alpha+\beta<1
$$

Where, $\mathrm{Y}(\mathrm{t})$ is the economy's output level, $\mathrm{K}(\mathrm{t})$ the physical capital level, $\mathrm{H}(\mathrm{t})$ the human capital level, $\mathrm{A}(\mathrm{t})$ factor productivity, and $\mathrm{L}(\mathrm{t})$ quantity of worker. Using some mathematical devices, the model can be presented as a logarithm of the product per worker, as (2):

$$
\ln \left[\frac{Y(t)}{L(t)}\right]=a+\frac{\alpha}{1-\alpha-\beta} \ln \left(s_{k}\right)+\frac{\beta}{1-\alpha-\beta} \ln \left(s_{h}\right)-\frac{\alpha+\beta}{1-\alpha-\beta} \ln (n+g+\delta)
$$

Where $s_{k}$ represents the investment in physical capital and $s_{h}$ the investment in human capital.

Acemoglu, Gallego, \& Robinson (2014), when discerning about the role of institutions in the economic growth of countries, affirm that physical capital, technology and human capital are economic growth itself, but not determinant of it as institutions. Therefore, they argue that models that do not properly control the effect of institutions on activity level tend to suffer from a serious omitted variable bias, overestimating the effect of human capital variables on output.

Thus, given the empirical limitations of the Mankiw, Romer, \& Weil (1992) model regarding the treatment of country-specific institutional factors, equation (3) is inserted into the model to explain the impacts of human capital on growth. via institutions. Formally: 


$$
\frac{\beta}{1-\alpha-\beta}=\delta_{0}+\delta_{1} \ln I
$$

Where $I$ is a vector of institutions for each country.

Based on Acemoglu, Johnson, \& Robinson (2001), it is expected that institutions positively affect the parameter $\frac{\beta}{1-\alpha-\beta}$, because better institutions tend to enhance the effect of human capital on GDP. This is because, according to the authors, more institutionally developed countries tend to organize human capital more efficiently - for example, through better labor organization and management - thus increasing the Human Capital-GDP elasticity.

Combining 2 and 3, we have the interactive variables model (Note 6), 4, from which it is possible to infer the influence of institutions on the impact of human capital on the level of activity of countries.

$$
\ln \left[\frac{Y(t)}{L(t)}\right]=\mu+\frac{\alpha}{1-\alpha-\beta} \ln \left(s_{k}\right)+\lambda \ln \left(s_{h}\right) *(\ln I)-\frac{\alpha+\beta}{1-\alpha-\beta} \ln (n+g+\delta)
$$

According to Wooldridge (2013), interactive terms are used to obtain partial effects, elasticities or semi-elasticities of the dependent variable with respect to explanatory variables dependent on other explanatory variables. Thus, the total effect of education on GDP per capita is not only measured by the coefficient for the education variable, but also by the interaction coefficient between this variable and the institutions.

\section{Database and Methodology}

To reestimate Mankiw, Romer, \& Weil (1992) model - or Augmented Solow model - through the insertion of institutions as a factor determining output via the effect of human capital, institutions are considered as determinants of the Human Capital-GDP elasticity. The sample comprises 87 countries for the years 2000, 2005 and 2010 (Note 7).

The dependent variable, GDP per capita (GDP_pc) was taken from UNCTADSTAT, United Nations (Note 8). Regarding the explanatory variables we have:

The investment variable $(f b c f)$ in Mankiw, Romer, \& Weil (1992) is measured as real investment as a percentage of GDP, however, the gross fixed capital formation in current millions of dollars (US\$) taken from the World Bank (2016) is used, which has a positive expected relationship with the dependent variable, GDP per capita.

Withdrawal from UNCTADSTAT, United Nations, the size of the workforce (ftrab) is measured in thousands with both sexes and all sectors of activity grouped. According to Mankiw, Romer, \& Weil (1992), the variable has a negative expected relationship with the dependent variable, because the increase in the workforce, or in the general population, reduces per capita income even though it contributes to increase gross income.

Total factor productivity ( $p t f)$, according to Sasseron (2016), is the measure of effectiveness with which factors of production are used to produce goods and services, being a function of GDP(Y), fixed capital (K), labor (L) and human capital (H) (Note 9) (5):

$$
p t f(t)=A(t)=\frac{Y}{K(t)^{\alpha}[H(t) L(t)]^{1-\alpha}}, \alpha \in[0,1]
$$

$p t f$ is used to measure country technology and although it is treated as common for all countries in Mankiw, Romer, \& Weil (1992), it distinguishes it between different countries. It has a positive expected relationship with the dependent variable GDP per capita.

As a proxy for human capital, unlike Mankiw, Romer, \& Weil (1992), which uses the percentage of the working-age population enrolled in secondary education, it is employed based on Queirós (2014) and Moral-Benito \& Bartolucci (2012), the variable elaborated by Barro \& Lee (2013), which represents the average education of the population over 25 years old $(e d u c)$. The variable has a positive expected relationship with the dependent variable.

Based on Acemoglu, Johnson, \& Robinson (2005) and Souza Júnior (2013), the institutional effect on the impact of human capital on GDP per capita is discerned in political and economic institutions. Both variables have a positive expected effect on the dependent variable.

For political institutions, we use the democracy variable (democ) of the Polity IV index, as it seeks to measure the quality of democracy, including the guarantees related to freedom of expression and association (SOUZA JÚNIOR, 2013). According to Glaeser, Porta, Lopez-Desilanez, \& Shileifer (2004), democracy in Polity IV reflects the extent to which the three essential interdependent elements are respected: the presence of institutions and procedures through which citizens can express preferences about alternative policies and leaders; the existence of institutional restrictions on the exercise of power by the executive; and guaranteeing civil liberties for all citizens in their daily lives and in acts 
of political participation (Note 10).

For economic institutions, characterized by North (1990) as institutions that affect the performance of the economy through its effects on exchange and production costs, the global measure of economic freedom is used in the Index of Economic Freedom (2016), overall, which includes property rights, freedom from corruption, tax, business and others. Thus, under the assumption that institutions influence the impact of human capital on output, the logarithm of equation 1 can be rewritten in terms of panel data (6).

$$
\ln y_{i t}=B_{0}+\ln p t f_{i t} B_{1}+\ln f b c f_{i t} B_{2}+\ln f t r a b_{i t} B_{3}+\ln h_{i t} B_{4}+\ln h_{i t} * \operatorname{democ}_{i t} B_{5}+\ln h_{i t} * \ln \text { overall }_{i t} B_{6}+\varepsilon_{i t}
$$

In methodological terms, we use the technique of Pooled Ordinary Leasts Squares (POLS), estimates by Ordinary Least Squares (OLS) for panel data, with control for data robustness and autocorrelation of the explanatory variables with regression residues.

According to Hsiao (1986), panel data models offer advantages over cross-sectional or time series models, such as: i) controlling the heterogeneity present in individuals and ii) allowing the use of more observations, increasing the degrees of freedom and decreasing collinearity between explanatory variables.

The general model for panel data is represented by (7):

$$
y_{i t}=\beta_{0 i t}+\beta_{1 i t} x_{1 i t}+\ldots+\beta_{k i t} x_{k i t}+\varepsilon_{i t}
$$

In this notation, the subscript $\mathrm{i}$ denotes the different individuals and the subscript $\mathrm{t}$ the time period. $\beta_{0 i t}$ refers to the intercept parameter and $\beta_{\text {nit }}(\mathrm{n}=1, \ldots, \mathrm{k})$ to the angular coefficient corresponding to the $\mathrm{k}^{\text {th }}$ model explanatory variable.

According to Wooldridge (2002), under hypotheses 1 and 2 below, the estimators of the coefficients of the variables in the POLS model are consistent and asymptotically normal. That is, the hypotheses imply conditional exogeneity of the error term with the explanatory variables, and no perfect collinearity between them.

$$
\begin{aligned}
& \text { Hypothesis 1: } E\left(x_{t}{ }^{\prime} u_{t}\right)=0, t=1,2, \ldots, T . \\
& \text { Hypothesis 2: } \operatorname{rank}\left[\Sigma_{t=1}^{T} E\left(x_{t}{ }^{\prime} x_{t}\right)\right]=K .
\end{aligned}
$$

To apply the usual OLS statistics in a POLS regression model with i objects and time periods, Wooldridge (2002) highlights the need for homoscedasticity (a), which means not only that the conditional variance of the error term is not associated with explanatory variables as well as being constant in time and absence of serial autocorrelation (b), expressed in hypothesis 3 (10 and 11).

$$
\begin{gathered}
\text { (a) } E\left(u_{t}^{2} x_{t}{ }^{\prime} x_{t}\right)=\sigma^{2} E\left(x_{t}{ }^{\prime} x_{t}\right), t=1,2, \ldots, T, \text { where } \sigma^{2}=E\left(u_{t}^{2}\right) \forall t \\
\text { (b) } E\left(u_{t} u_{S} x_{t} x_{S}\right)=0, t \neq s, \quad t, s=1, \ldots, T .
\end{gathered}
$$

\section{Results Analysis}

The model estimation was structured by grouping the variables into cross-sections. It is worth noting that because the estimation is made using panel data, the coefficient results are interpreted as an average response for the group of countries analyzed.

Worth mentioning, a high correlation between the variables of institutions and human capital may generate a bias multicollinearity - a fact that would justify the omission of institutions in the model, thus approving the original model developed by Mankiw, Romer, \& Weil (1992). However, Table 1 indicates that the correlation of institutional variables - democracy and economic freedom - with the total productivity of factors of production (0.4687 and 0.5355), and human capital (0.4195 and 0.3483), with gross fixed capital formation (0.3402 and 0.3004) and labor force (-0.0774 and -0.2091) proving insufficient to claim 'near-perfect' collinearity of institutions with the other explanatory variables thus discard the possibility of bias. In addition, it is suggested that institutions of the model should not be omitted because, although the correlations are not high enough to generate bias, they are significant to infer direct relationships between institutions and the explanatory variables of the model by Mankiw, Romer, \& Weil (1992) - human capital, productivity, labor force and gross physical capital formation -, thus allowing to extract indirect relations with the level of economic activity.

For the total factor productivity, for example, it is coherent that it is better correlated with economic institutions 
(0.5355), because, according to Acemoglu, Johnson, \& Robinson (2005), they are directly linked to the economic performance of societies. Although investment in fixed capital has a positive correlation for both institutional variables, it has a higher correlation with political institutions (0.3402), since longer maturity investments require greater confidence in the country's political structure and validity of property rights. According to Acemoglu, Johnson, \& Robinson (2005), political institutions form the basis of the dynamic relationship between institutions, resource distribution and economic performance. Thus, for the representative variable of human capital, the logarithm of the average education level of the adult population, a better correlation with the political institutions is noted ( 0.4195$)$.

Table 1. Correlation between institutions and other explanatory variables

\begin{tabular}{ccc}
\hline & democ & lnoverall \\
\hline ln_fbcf & 0.3402 & 0.3004 \\
ln_ftrab & -0.0774 & -0.2091 \\
ln_ptf & 0.4687 & 0.5355 \\
ln_educ & 0.4195 & 0.3483 \\
\hline
\end{tabular}

Source: Based on database from UNCTADSTAT, World Bank, Barro \& Lee (2013), Polity $\quad$ IV and

Index of Economic Freedom (2016).

It is worth noting that the correlations produce evidence in favor of the hypothesis presented by Acemoglu, Gallego, \& Robinson (2014). That is, despite the high correlation between GDP per capita and the explanatory variables of the Augmented Solow Model (Appendix 1), there is a considerable correlation between the explanatory variables and the institutions (Table 1), suggesting that: institutions determine the explanatory variables of the Augmented Solow model, which determine the economic growth.

Table 2 presents the results of estimating the average variation of the effects of explanatory variables on GDP per capita of 87 countries using the POLS method (Note 11). As observed, the variable that measures labor participation, ln_ftrab, is significant at 5\% and negatively related to GDP per capita. That is, a 10\% increase in the workforce reduces GDP per capita by approximately $1.3 \%$. This result is compatible with Mankiw, Romer, \& Weil (1992), because, according to the authors, higher population growth reduces income, because the capital product is distributed in smaller proportions to the working population. The same holds true for the augmented model, where the product of human capital is also dispersed in smaller proportions, causing population growth to reduce the measure of total factor productivity.

Table 2. Regression - dependent variable: GDP_pc logarithm

\begin{tabular}{ccc}
\hline Exogenous Variables & Coef. & t-statistics \\
\hline ln_fbcf & $0.1500^{* *}$ & 2.56 \\
ln_ftrab & $-0.1349^{* *}$ & -2.22 \\
ln_ptf & $1.3965^{* * *}$ & 12.63 \\
ln_educ & $0.5056^{* *}$ & 2.50 \\
educ_democ & $0.0010^{*}$ & 1.73 \\
educ_overall & $0.1357^{* * *}$ & 2.95 \\
_cons & $-4.8100^{* * *}$ & -5.09 \\
$R^{2}$ & 0.9766 & \\
Observations & 256 & \\
\hline
\end{tabular}

Sig: $p<0.1 * ; * * p<0.05 ; * * * p<0.01$

Source: Prepared from estimates.

On the other hand, the variables that measure the participation of investment ( $\left.\ln \_f b c f\right)$, total factor productivity (ln_ptf) and human capital (ln_educ) are significant at 5\%,1\% and 5\% respectively. The variables are positively related to GDP per capita, indicating that, on average, a $10 \%$ increase in $\ln \_$fbcf (or ln_ptf, or ln_educ) leads to an increase of approximately $1.5 \%$ (or $13.9 \%$ or $5 \%$ ) (Note 12) in GDP per capita. These results are in agreement with Mankiw, Romer, \& Weil (1992), because an increase in investments (fbcf) in the economy has a positive impact on steady state 
income, contributing to the growth of human capital, although the accumulation rates of other factors remain unchanged. According to the authors, higher savings rates lead to growth in the total productivity of factors that, with the inclusion of the human capital variable in the model, differ quantitatively from the results of Solow (1956). Higher investments in human capital positively influence the per capita income of countries, with different educational policies determining the disparities and income convergences between countries.

These results are consolidated in the literature by Mankiw, Romer, \& Weil (1992). The contribution of this paper is to identify how the effect of human capital on GDP per capita is reinforced as the institutional factor is inserted in a model of interactive variables.

According to table 2, both human capital interacting with economic institutions, educ_overall, as with political institutions, educ_democ, there is significance of the parameters at least $10 \%$ of significance. In addition, both are positively related to GDP per capita, indicating that the institutional factor amplifies the effect of human capital on GDP per capita.

Based on the interpretation of the interactive variables, the relationship between the positive percentage change in human capital and the GDP per capita is evaluated as:

\section{$0.5056+0.0010$ demod +0.1357 (lnoverall)}

Analyzing the coefficients of interactive terms, it is observed that the reinforced effect of human capital on GDP per capita is greater compared to a change in the indicator of economic institutions, overall, than for a change in the indicator of political institutions. That is, assuming the absence of the latter $(\mathrm{democ}=0)$, it is estimated that the effect of human capital on GDP per capita is higher on average compared to the case where the indicator of economic institutions, was equal to zero and political institutions were nonzero. However, when considering joint effects, that is, democ and lnoverall non-zero, human capital has the greatest impact on GDP per capita. That is, observing the descriptive statistics (Appendix 3), it is known that the minimum values of the variables democ and lnoverall are, respectively, 0 and 21.4; thus, the isolated value of the coefficient of ln_educ (0.5056) cannot be interpreted by assuming zero for lnoverall. However, the mean partial effect of marginal variation of human capital on GDP per capita can be interpreted by entering the mean values of democ and lnoverall; respectively 6.7241 and 4.1052 , obtaining the final effect of 1.0693 .

$$
0.5056+0.001(66.7241)+0.1357(4.1052,
$$

In fact, such a coefficient is approximately obtained for the education variable by subtracting the respective means from institutional variables - democracy and economic freedom - and performing the same regression procedure with interactive variables. Thus, for the average values of lnoverall and democ, a $10 \%$ increase in the human capital indicator, ln_educ, causes the GDP per capita to vary by approximately $10.693 \%$.

In summary, despite the greater correlation with political institutions (Table 2), the effect of schooling on GDP per capita is further driven by the countries' economic institutional indicator. Based on Acemoglu, Johnson, \& Robinson (2005), this result indicates that although political institutions determine the formal power of society (de jure) and, together with the distribution of resources, influence economic institutions by union with effective political power (de facto), it is the economic institutions that determine the economic performance of countries, both in terms of growth and in the distribution of resources in later periods.

Souza Júnior (2013) finds a negative result for the effect of political institutions on the estimation of per capita income and draws attention to the possible counter intuitiveness of the relationship found, stating that there is no consensus in the literature about the direction and magnitude of the effects of political institutions on per capita income. However, it highlights the possibility that this indicator has positive indirect effects due to its ability to improve economic institutions and suggests that the negative effect is due to the distributional effects of democracy, such as downward wage rigidity due to union consolidation, for example.

It is noteworthy that according to Glaeser, Porta, Lopez-Desilanez, \& Shileifer (2004), indicators associated with economic institutions, related to property rights, government effectiveness, subjective risk assessments for international investors along dimensions such as law and order, bureaucratic quality, corruption, the risk of government expropriation, and the risk of government contract repudiation, may not identify dictatorial governments concerned about keeping such indicators at a reasonable level rather than the effective performance of political institutions, such as legislative restrictions on the executive branch, for example; in fact, according to the authors, it is included in the democracy variable of the Polity IV base. 


\section{Conclusions}

The objective of the study was to verify whether institutions, omitted by both the Solow Model and the Augmented Solow Model, can be considered country specificities and thus a differential factor to explain the effect of human capital on GDP per capita. The panel data methodology with interactives variables was used for the years 2000,2005 and 2010 for 87 countries.

Because they are more closely related to economic performance, it has been found that, statistically, economic institutions better drive the effect of human capital on countries' GDP per capita, showing that the effectiveness of political power and its immediate impacts on a country's output. It can often be more effective than attempts at long-term institutionalization of political power.

In short, against the background of institutionalist theory and economic growth theory, the results suggest a new way of viewing the relationship between growth and human capital. In addition to Mankiw, Romer, \& Weil (1992) - which capture only the direct effects of human capital on country growth - in this new perspective, it is found that the effect of human capital on economic growth is reinforced to the extent that This institution is inserted, indicating that countries with better institutional levels result in greater efficiency of the effects of human capital on growth - increasing the angular coefficient of human capital on GDP. This greater efficiency may reflect factors such as correctly targeted public spending, better knowledge transmission between people (social capital), investor confidence in the public and private sectors of countries, among others (Note 13).

\section{References}

Acemoglu, D. (2009). Introduction to modern economic growth. Princeton: Princeton University Press.

Acemoglu, D., D. Gallego., \& Robinson, J. (2014). Institutions, Human Capital, and Development. Annual Review of Economics, 6(1), 875-912. https://doi.org/10.1146/annurev-economics-080213-041119

Acemoglu, D., S. Johnson., \& Robinson, J. (2001). The Colonial Origins of Comparative Development: An Empirical Investigation. American Economic Review, 9(5), 1369-1401. https://doi.org/10.1257/aer.91.5.1369

Acemoglu, D., S. Johnson., \& Robinson, J. (2005). Institutions as a Fundamental Cause of Long-Run Growth, IN: P. Aghion \& S. N. Durlauf (Eds), Handbook of Economic Growth, IA, Elsevier North-Holland, Amsterdam, The Netherlands, pp. 385-472. https://doi.org/10.1016/S1574-0684(05)01006-3

Acemoglu, D., S. Johnson., Robinson, J., Yared, P. (2008). Income and Democracy. The American Economic Review, 98(3), 808-842. https://doi.org/10.1257/aer.98.3.808

Barro, R. J., \& Lee, J. W. (2013). A new data set of educational attainment in the world, 1950-2010. Journal of Development Economics, 104,184-198. https://doi.org/10.1016/j.jdeveco.2012.10.001

Coleman, J. (1988). Social capital in the creation of human capital. Am. J. Sociol, 94, S95-121. https://doi.org/10.1086/228943

Dias, J., Dias, M. H. A., \& Lima, F. F. de. (2009). Os efeitos da política educacional no crescimento econômico: teoria e estimativas dinâmicas em painel de dados. Revista de Economia Política, 29(3) (115), 232-251. https://doi.org/10.1590/S0101-31572009000300013

Domar, E. D. (1946). Capital expansion, Rate of Growth, and Employment. The Economic Journal, $14(2), 137-147$. https://doi.org/10.2307/1905364

Glaeser, L., Porta, R., Lopez-Desilanez., \& Shileifer, A. (2004). Do Institutions Cause Growth? Journal of Economic Growth, 9(3), 271-303. https://doi.org/10.1023/B:JOEG.0000038933.16398.ed

Hall, R., \& Jones, C. (1999). Why Do Some Countries Produce So Much More Output per Worker than Others? Quarterly Journal of Economics, 114(1), 83-116. https://doi.org/10.1162/003355399555954

Hargens, L. L. (2009). Product-variable models of interaction effects and causal mechanisms. Social Science Research, 38(1), 19-28. https://doi.org/10.1016/j.ssresearch.2008.05.003

Harrod, R. (1939). An Essay in Dynamic Theory. The Economic Journal, 49(193), 14-33. https://doi.org/10.2307/2225181

Hsiao, C. (1986). Analysis of Panel Data. Cambridge, Cambridge University Press.

Index of Economic Freedom. (2016). The Heritage Foundation, Washington.

Lopes, T. H. C. R. (2015). Democracia, Confiança e Crescimento Econômico. 163 f. Universidade Federal de Minas Gerais. 
Mankiw, G., Romer, D., \& Weil, D. (1992). A contribution to the empirics of economic growth. The Quarterly Journal of Economics, 107(2), 407-438. https://doi.org/10.2307/2118477

Moral-Benito, E., \& Bartolucci, C. (2012). Income and democracy: Revisiting the evidence. Economics Letters, 117(3), 844-847. https://doi.org/10.1016/j.econlet.2012.08.045

North, D. C. (1981). Structure and change in economic history. New York: W. W. Norton \& Co.

North, D. C. (1990). Institutions, institutional change, and economic performance. Cambridge, Cambridge University Press: New York. https://doi.org/10.1017/CBO9780511808678

North, D. C. (1991). Institutions. The Journal of Economic Perspectives, 5(1), 97-112. https://doi.org/10.1257/jep.5.1.97

Putnam, R. (1996). Comunidade e Democracia: a experiência da Itália moderna. Rio de Janeiro, Fundação Getúlio Vargas.

Queirós, A. (2014). Crescimento económico, capital humano e especialização produtiva: uma análise empírica. 72 f. Dissertação (Mestrado em Economia) Faculdade de Economia da Universidade do Porto.

Rennó, L. R. (2001). Confiança Interpessoal e Comportamento Político: microfundamentos da teoria do capital social na América Latina. Opinião Pública, 7(1), 33-59. https://doi.org/10.1590/S0104-62762001000100003

Sasseron, R. H. (2016). Determinantes da produtividade: análise do impacto do índice GCI e seus componentes sobre a $P T F$. Dissertação de mestrado - Faculdade de Economia, Administração e Contabilidade de Ribeirão Preto FEA-RP. Universidade de São Paulo.

Solow, R. (1956). Contribution to the Theory of Economic Growth. The Quarterly Journal of Economics, 70(1), 65-94. https://doi.org/10.2307/1884513

Souza Júnior, J. (2013). Qualidade da Instituições: estimação de indicadores agregados, de seus determinantes e de seus efeitos sobre a renda per capita. $191 \mathrm{f}$. Universidade Federal de Minas Gerais.

Wooldridge, J. M. (2002). Econometric analysis of cross section and panel data. Cambridge, Cambridge: The MIT Press.

Wooldridge, J. M. (2013). Introdução à Econometria - Uma Abordagem Moderna (4a. ed). São Paulo, Cenage Learning.

World Bank. (2016). World Bank national accounts data, 2015 update. Washington, D.C.: 2015. Disponível em: < http://data.worldbank.org/indicator/NY.GNS.ICTR.ZS>. Acesso em: 16 set. 2016. WORLD BANK.

\section{Notes}

Note 1. See Solow (1956).

Note 2. Mankiw, Romer, \& Weil (1992) state that human capital is influenced by the rate of savings and population growth, just as the fraction of income influences the magnitude of its coefficients, so that its omission would bias the coefficients of these terms in regression. Thus, by inserting human capital into the product equation, the authors minimize the role of savings in the speed of convergence between incomes.

Note 3. North (1981) attributes the lack of property rights over innovation to be a major factor in the slow pace of technological change over time.

Note 4. According to Rennó (2001, p. 36): “[...] trust reinforces collective action and cooperation, because it is based on expectations of the continuity of established and repetitive behavior patterns".

Note 5. In Solow's Model (1956), the omission of human capital would put it in the error term $\varepsilon$.

Note 6. The interactive variable model is an extension of the hierarchical models, however, differs from them in assuming that the heterogeneity of the parameters is the result of characteristics specific to the cross-section unit (HARGENS, 2009).

Note 7. Due to the scarcity of information on education and work for a large set of countries, only the years 2000, 2005 and 2010 were considered in the empirical exercise. An analysis with a small group of countries would reduce data variation and thus affect the statistical properties of the estimators. The countries Analyzed are: Albania, Algeria, Argentina, Armenia, Australia, Austria, Bahrain, Bangladesh, Belgium, Bolivia, Brazil, Bulgaria, Cambodia, Cameroon, Canada, Chile, China, Colombia, Congo Dem. Rep., Costa Rica, Cote d'Ivoire, Croatia, Cyprus, Czech Republic, Denmark, Ecuador, Egypt Arab Rep., Estonia, Finland, France, Germany, Ghana, Greece, Guatemala, Hungary, India, Indonesia, Iran Islamic Rep., Ireland, Israel, Italy, Japan, Jordan, Kazakhstan, Kenya, Latvia, Lithuania, Luxembourg, Malawi, Malaysia, Mali, Mexico, Morocco, Mozambique, Netherlands, New Zealand, Niger, Norway, Peru, Philippines, Poland, Portugal, Qatar, Romania, Russian Federation, Saudi Arabia, Senegal, Singapore, Slovak Republic, Slovenia, 
South Africa, Spain, Sri Lanka, Sudan, Sweden, Switzerland, Tajikistan, Thailand, Tunisia, Turkey, Uganda, Ukraine, United Kingdom, United States, Uruguay, Vietnam, Zimbabwe.

Note 8. Mankiw, Romer, \& Weil (1992) use the variable GDP per capita instead of GDP per effective worker, suggested by Solow (1956).

Note 9. Based on Sasseron (2016), the share of capital in the production function is adopted as $0.4 \alpha=0,4$ ).

Note 10. The democracy index has a scale from zero to ten $(0-10)$. Due to the presence of many countries with zero index scores, the natural logarithm feature was not used in this variable in the regression.

Note 11. In order to verify the presence of endogeneity in the model, a regression of the residuals against the explanatory variables was applied (Appendix 2). Considering one decimal digit, the $t$ statistics of the parameters equals to zero suggest that there is no correlation between the term of the error and the explanatory variables, indicating the consistency of the estimates of equation 6 by POLS.

Note 12. Assuming that there is no effect of institutions educ_democ $=e d u c_{-}$overall $=0$.

Note 13. See Coleman (1988) and Putnan (1996).

\section{Appendices}

Appendix 1. Correlation between GDP per capita and explanatory variables of the Increased Solow Model

\begin{tabular}{c|c}
\hline & lnGDP_pc \\
\hline ln_fbcf & 0.6259 \\
Ln_ptf & 0.9149 \\
ln_educ & 0.6969 \\
ln_ftrab & -0.1968 \\
\hline
\end{tabular}

Source: Prepared from estimates.

Appendix 2. Residuals autocorrelation test

\begin{tabular}{ccc}
\hline Residual & coeficent & t-statistics \\
\hline ln_fbcf & $-1.22 \mathrm{E}-09$ & 0.0 \\
ln_ftrab & $-1.57 \mathrm{E}-09$ & 0.0 \\
ln_ptf & $-1.53 \mathrm{E}-09$ & 0.0 \\
ln_educ & $3.14 \mathrm{E}-09$ & 0.0 \\
educ_democ & $1.03 \mathrm{E}-11$ & 0.0 \\
educ_overall & $1.19 \mathrm{E}-09$ & 0.0 \\
_cons & $1.76 \mathrm{E}-08$ & 0.0 \\
$R^{2}$ & 0.9766 & \\
observations & 256 & \\
\hline
\end{tabular}

Source: Prepared from estimates.

Appendix 3. Descriptive statistics

\begin{tabular}{cccccc}
\hline & obs & mean & $\begin{array}{c}\text { standard } \\
\text { deviation }\end{array}$ & Min & max \\
\hline GDP_pc & 261 & 17.866 & 21.173 & 286 & 101.221 \\
fbcf & 261 & 10.663 .333 & 32.256 .581 & 7.007 & 71.981 .759 \\
ftrab & 261 & 29.914 & 107794 & 246 & 965.523 \\
ptf & 261 & 202.51 & 131.45 & 27.54 & 581.9 \\
educ & 261 & 8.32 & 3.09 & 0.91 & 13.42 \\
democ & 261 & 6,72 & 3,64 & 0 & 10 \\
overall & 256 & 61.61 & 10.34 & 21.4 & 87.7 \\
\hline
\end{tabular}

Source: Based on database from UNCTADSTAT, World Bank, Barro \& Lee (2013), Polity

IV and Index of Economic Freedom (2016).

\section{Copyrights}

Copyright for this article is retained by the author(s), with first publication rights granted to the journal.

This is an open-access article distributed under the terms and conditions of the Creative Commons Attribution license which permits unrestricted use, distribution, and reproduction in any medium, provided the original work is properly cited. 